\title{
Relationship between economic infrastructure and foreign direct investment within the framework of foreign aid in the MENA region
}

\section{Amira tohamy eltaib}

\begin{abstract}
The aim of this paper is to study the interaction between aid allocated to infrastructure and the actual level of that infrastructure; as well as the impact of such interaction on the net inflows of foreign direct investment to the Middle East and North Africa (MENA) region. In order to achieve this goal, the simultaneous equations model used in the study of Donaubauer, Nunnenkamp (2015) was partially modified to make it suitable for the conditions of the MENA region; and the three-stages least squares (3 SLS) method was applied. The study results reveal a strong positive impact of infrastructure on foreign direct investment. Raising by one point the economic infrastructure index leads to an increase of $6 \%$ to $7 \%$ of GDP in foreign direct investment inflows to the MENA countries. The various conducted robustness tests also prove that such impact is robust and stable. However, foreign direct investment inflows are only indirectly influenced by aid via the channel of the actual infrastructure level. At the sectors' level, the infrastructure of the information and communications technology sector had the greatest effect on attracting foreign direct investment to the MENA region, followed way behind by the infrastructure of the transport sector, then by the infrastructure of the financial sector and finally the infrastructure of the energy sector.

Keywords: Economic infrastructure, aid, foreign direct investment, MENA region, Simultaneous equations, the 3SLS method.
\end{abstract}




\section{Introduction}

Foreign direct investment is an essential pillar of economic growth. It largely contributes to the development and transformation of the MENA region especially through establishing new industries, enhancing productive capacity, creating employment opportunities, increasing trade and improving technological capacity. When we examine the ratio of net inflows of foreign direct investment to the GDP of the MENA region countries during the study period (2000 - 2017), we note that that ratio is rather low in most countries, as shown in Figure (1). For instance, in Yemen, that ratio ranged from a maximum of $5.88 \%$ in 2006 to a minimum of $-1.08 \%$ in 2016. In the Kingdom of Saudi Arabia that ratio fluctuated between a maximum of $8.5 \%$ in 2008 and a minimum of $-0.99 \%$ in 2000 , while recording a negative value in several years. In Egypt, the same ratio ranged from a low of $0.2 \%$ in 2011- perhaps due to the political circumstances of that year- and a maximum of $9.3 \%$ in 2006 . Similar levels were observed in the other MENA countries, with the exception of Djibouti where this ratio fluctuated from a high of approximately $23 \%$ in 2007 to a low of $0.6 \%$ in the years 2000 , 2001, and 2002.1

Source: www.worldbank.org, World Development Indicators1 
Figure (1): Historical evolution of the net inflows of foreign direct investment as a ratio of GDP in the MENA countries during the period 2002-2017

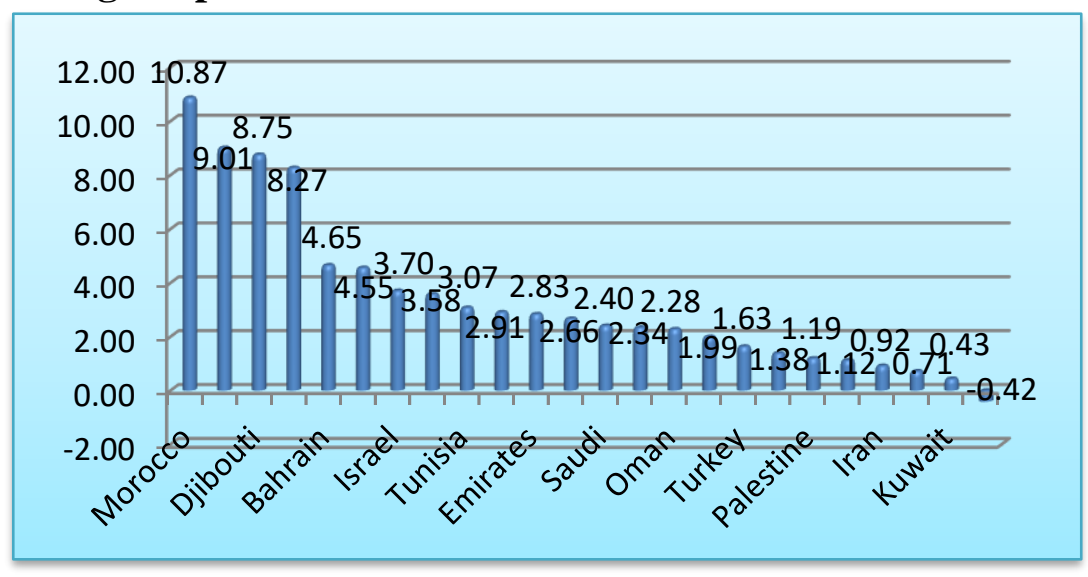

Generally speaking, during the past eighteen years, foreign direct investments contributed only a minor part of GDP in the MENA countries. Therefore, there is need for attracting more foreign investments to these countries. A crucial factor for achieving this goal is improving the infrastructure of the services sectors and in particular, the financial services, the information and communications technology, the energy and the transport sectors. Emerging countries such as China, India and Vietnam, are strong competitors for foreign direct investments, given their ability to provide cheap labor in large numbers, thus enjoying an important edge in comparison to the other developing countries.

Actually, a good infrastructure is a necessary condition for giving foreign investors the opportunity to realize successful projects. A weak infrastructure and/or unavailable public utilities represent higher costs of production for multinationals and consequently lower profit margins. In other words, a strong infrastructure provides an adequate climate for foreign direct investment via reducing costs and increasing returns. (Khadaroo, J.A. and 
Seetanah, B., 2010).2 The study of Wei, S. (2000) stresses that a site endowed with a good infrastructure is more attractive to foreign direct investment than the other sites.

Therefore if any country in the MENA region can offer an incentive to foreign investments through the reduction of business costs, especially transport costs, that would lead to increasing the inflows of foreign direct investment which in turn may increase the size of foreign trade (Ahmad, N.A., 2015). We deduce that MENA countries need to establish an infrastructure of international standard to backup their economic activities and accelerate their economic development. An inefficient infrastructure would impede any of these countries from fully benefitting from its potential capabilities, whatever the progress realized in other domains.

In addition to reducing production costs of foreign investments, an efficient infrastructure would enhance the productivity of local industries and in this way provide a better business climate and an additional incentive for foreign direct investment (Asiedu, 2002, p.111). Aid in infrastructure may become a further means of FDI attraction since foreign investors may be convinced that a foreign-aid financed infrastructure enjoys a higher quality than a locally-financed infrastructure. (Mayer, E., 2006). Although until the present time, research studies tackling the impact of financial aid on economic growth have failed to offer robust and convincing results in this respect (Rajan an Subramanian, 2008; and Roodman, 2007).

Using infrastructure data at the sectors' level, the present paper focuses on infrastructure and aid in infrastructure, and studies the interaction of these two variables as main determinants of FDI

For more readings, see: Wheeler and Mody (1992); Lorce and Guisinger (1995); 2 Richard et al. (1999); Asiedu (2002); Morrisset (2000); Sekkat and VeganzonesVaroudakis (2004); and Quazi (2005). 
inflows to the MENA countries during the study period 20002017.

Next to the Introduction, this paper covers the following items: A historical review of relevant studies is presented in Section 2; the experimental characteristics of the study model and the description of its variables are discussed in Section 3; the econometric analysis and experimental results are displayed in Section 4; finally, in Section 5, results and deductions of the study and recommendations for future studies are presented.

\section{Previous studies}

Worldwide, countries of various income levels compete for improving their business climate and for attracting bigger inflows of foreign direct investment, given its importance for driving up economic growth especially in the field of technical experience and technology transfer. Relatively advantageous infrastructure aspects are considered crucial factors in determining the competitiveness of various economies in attracting foreign direct investment, through reducing total investment costs. Recently, the economic literature has aroused a wide debate about the impact of infrastructure, in its different forms, on attracting increasing inflows of foreign direct investment. Most applied studies concluded that the infrastructure level has a strong positive effect on foreign direct investment, whether taken at the level of a single country or a group of countries, and whether using individual sector indexes or cross-section indexes.

Among studies using sectional data, the study of Khadaroo and Seetanah (2010) was applied to twenty African countries and concluded that transport infrastructure contributed to the relative attractiveness of the country for foreign direct investment. Shah (2014) also found that, in ninety developing countries, infrastructure as measured by the intensity of telephone communications had a positive effect on the choice of foreign investment sites. However, the researcher warned that that result 
was sensitive to the proxy variable chosen to represent infrastructure; although it seemed robust under the specifications of the study model. Similarly, Michiels (2018) aimed at analyzing the impact of various forms of infrastructure on foreign direct investment in African countries. In most cases, strong relationships between a large myriad of infrastructure variables and foreign direct investment were revealed although such a finding was unexpected in the case of infrastructure in the communications and electricity supply sectors. On the other hand, infrastructure in the transport sector did not appear influential. Furthermore that study did not reveal any foreign aid contribution to the investments of African governments in infrastructure, in view of attracting foreign direct investment.

Results of research papers tackling the relationship at the level of a single economy were not different from those of studies based on sectional data in a group of countries. The studies of Bakar (2012) and Ahmad et al. (2015) applied to Malaysia, and the study of Rehman (2011) about the Pakistani economy also found a positive relationship between the standard of infrastructure and foreign direct investment in those countries. This indicates that foreign investors carefully analyze the condition of infrastructure in the targeted countries before selecting their investment sites. A bad infrastructure is usually reflected in higher costs and reduced profit margins, as well as inadequate relations with the rest of the World.

Despite the credibility of this theoretical relationship, application results were not conclusive as still a few studies found no impact of infrastructure on attracting foreign investment. For instance the study of Asiedu (2002) concluded that infrastructure was not an influential factor in Sub-Sahara African countries while having a positive impact in the rest of African countries (non SSA countries). Ogunjimi and Amune (2017) argued that infrastructure (in the form of tractors, telephone connection lines 
and electricity) had an influence on attracting foreign direct investment to Nigeria but only in the short-run; although the generation of electricity had a positive effect in the long-run.

Other studies endeavored to measure interaction relationships between infrastructure, foreign direct investment and economic growth. Hence, the study of Pradhan et al. (2013) as applied to India revealed that transport infrastructure, foreign direct investment and economic growth were correlated, thus indicating with certainty the existence of long-term equilibrium relationships between those three variables. The study concluded that if India needs to attract more inflows of foreign direct investment and increase its economic growth, then it should urgently proceed to the development of its transport infrastructure, as a pre-requisite for accelerating economic growth. Moreover bringing larger inflows of foreign direct investment to the country may in turn boost the development of the transport infrastructure and speed up economic growth. Similarly, keeping up high economic growth rates may accelerate the inflows of foreign direct investment and enhance the development of rapid transport infrastructure in India. Briefly, all the main variables positively interact within the economic development process.

Based on the interaction between infrastructure and foreign investment, the study of Kirkpatrick et al. (2004) evaluated the impact of organizational governance on foreign direct investment in infrastructure projects, in low and middle income economies among developing countries. The study underscored that foreign investment in infrastructure positively responded to the existence of an effective organizational framework able to endow the private sector with organizational credibility. Conversely, when organizational institutions are weak and exposed to being sequestrated by the government - or the private sector - foreign investors would probably refrain from being bound to invest big 
amounts in huge infrastructure projects in developing countries. Therefore, the study stressed the need to build up capabilities and reinforce institutions in order to establish a strong and independent organizational framework in the developing countries.

Within the same context, and given the extension of the infrastructure concept to encompass numerous new elements such as the institutional infrastructure, Globerman and Shapiro (2002) surveyed the effects of governance infrastructure on both the inflows and outflows of foreign direct investment in an extensive sample of developed and developing countries during the period 1995 -1997. The researchers concluded that governance infrastructure was one of the important factors influencing foreign investment inflows and outflows. Investing in governance infrastructure does not only attract foreign capital, but also provides the adequate conditions for establishing local multinationals that will invest abroad. Moreover, Globerman and Shapiro (2003) studied the statistical importance of governance infrastructure as a determinant of foreign direct investment in the United States of America. They used a two-stage analysis. In the first stage, they estimated the probability for a country to receive foreign direct investment and found that countries that failed to realize a minimum level of effective governance were not likely to receive any U.S. foreign direct investment. In the second stage, the analysis was limited to the countries which actually received inflows of U.S. foreign direct investment. The study concluded that governance infrastructure - including the quality of the legal system - was an important determinant of the received investment funds.

Within a more advanced framework, a few studies endeavored to measure the interactive relationships between aid allocated to infrastructure and the quality standard of that infrastructure, on one hand, and foreign direct investment on the other hand, in 
order to test the following assumptions: Do foreign investors believe that aid-financed infrastructure serves their purposes better than locally-financed infrastructure? Does aid-financed infrastructure focus more on the needs of foreign direct investment? Does it enjoy a higher quality standard? Or better maintenance due to the external control of aid donors?

As an example, the two studies of Vigil and Wagner (2012) and Donaubauer (2015) proved the strong positive impact of aid on aid-financed infrastructure, while other aid categories had no significant effect on infrastructure in developing countries. Furthermore, the study of Donaubauer (2015) revealed that aid allocated to infrastructure had a direct and an indirect effect on foreign direct investment through infrastructure.

Nevertheless, most of the current academic literature does not clearly indicate whether or not different types of infrastructure have different effects, although such information would be of great help to policy-makers who envisage investing in infrastructure in view of speeding up economic growth. Academic researchers should include in their models a proxy variable, i.e. the most representative element of infrastructure in relation to foreign direct investment. In addition, economic literature lacks sufficient studies which tackle the interactive relationship between economic infrastructure, aid funds allocated to that infrastructure, and foreign direct investment; especially concerning the MENA region. The present study is an attempt to fill this gap.

\section{The study model and variables}

This research paper aims at studying possible complementary aspects between aid and economic infrastructure and the impact of such relationship on foreign direct investment in the MENA region. It is assumed that aid specifically allocated to the economic infrastructure helps the MENA countries to attract larger inflows of foreign direct investment through improving 
their capacity to provide infrastructure in the sectors of transport, communications, energy and finance.

To test this assumption, we depend on the unbalanced panel data of a sample of 24 countries 3 representing all the countries in the region during the time period $(2000-2017)$ or 432 annual observations in total.

The following foreign direct investment equation can serve as the starting point of our empirical analysis. $F D I_{i t}=\alpha+\beta_{1}$ aid $_{i t}+\beta_{2}$ infrastructure $_{i t}+\beta_{3} X_{i t}+\varphi_{t}$ $+\varepsilon_{i t} \quad(1)$

where the dependent variable $(F D I)$ indicates the inflows of foreign direct investment as a ratio of the gross domestic product (GDP) of the receiving country $i$ in the year $t$. Two other explanatory variables of crucial importance in the abovementioned equation are: Aid and Infrastructure. The (aid in infrastructure) variable represents the annual inflows of aid and financial assistance funds allocated to the economic infrastructure of the receiving country $i$ in the year $t$. In further estimations, total aid in infrastructure will be replaced by aid sub-categories directed to specific subsidiary sectors, namely: Transport and Storage, Communications, Energy, and Banking and Financial Services. Aid funds, whether as a total or in all the other sectors (in the form of natural logarithms), are included as an independent variable. In an additional analysis, control variables are introduced and all the other independent variables are one-year lagged.

The infrastructure index has been calculated according to the methodology adopted by Donaubauer et al. (2015 a). In this study, the infrastructure index is based on a broad set of annual data representing 15 indexes concerning the quantity and quality of infrastructure. Hence, this inclusive index depends on a number 
of flow indexes and stock indexes. For example, the flights of air freight airlines and air freighted goods concerning the infrastructure of the transport sector; connection errors of landline phones in relation to the infrastructure of the information and communications technology (ICT) sector; energy consumption and electricity production in relation to the infrastructure of the energy sector; the number of bank branches and the private credit amounts advanced by banks concerning the financial infrastructure. This means that the present infrastructure index gives almost equal consideration to flow and stock indexes, thus gaining an edge over previous simpler indexes.

The inclusive index of economic infrastructure is calculated according to the methodology of the "Principal Component Analysis" (PCA) where a large set of possibly related variables is transformed into a small set of linearly uncorrelated variables called "principal components." Among these variables, the first principal component displays the largest possible variance. This methodology is implemented in the present study since it provides the researcher with a tool for dealing with complex information by realizing an optimum compatibility via reducing the number of variables describing the given data without losing the original information (variance) as a result of the reduction procedure. In our analysis, higher values of the composite index indicate a better infrastructure. In further estimations, we use four subsidiary infrastructure indexes in line with the corresponding aid categories allocated to infrastructure in the sectors of transport, information and communications technology, energy and finance. 4

In Equation (1) the term $X$ represents the vector of control variables which have been chosen in conformity with relevant

Infrastructure in each of the sectors of transport, communications and information 4 technology, and finance has been represented by four indexes; and by three indexes in the energy sector. 
previous studies. GDP per capita (natural logarithm) is used because income per capita in the receiving country usually explains the fact that foreign direct investment tends to be concentrated in developed countries. Moreover, in the crosssection estimations while including the fixed effects of the countries - as shown in Equation (1) - GDP per capita reflects to some extent the variance of incomes and relevant production costs in the investment receiving country over time. The size of $G D P$ (natural logarithm) and the rate of economic growth (GDP growth) of the receiving country have been incorporated as proxies of the size and growth of local markets which were proven in many cases the main attraction factor for foreign direct investment. Openness to trade of the host country is yet another variable driving up foreign direct investment. Openness to trade is defined as the country's total exports plus total imports taken as a ratio of GDP. A more adequate investment climate and low risks are certainly important encouraging factors for foreign direct investment, 5 in addition to the aid allocated to sectors other than the infrastructure. Finally, variables $\varnothing$ and $\varepsilon$ refer to the fixed effects of the country and to the error term respectively.

In order to resolve the problem of potential endogeneity between aid and infrastructure in Equation (1), we explicitly take into account their determinants in Equations (2) and (3) as follows:

$$
\begin{aligned}
& \operatorname{aid}_{i t}=\alpha_{a i d}+\beta_{1} \text { infrastructure needs } s_{i t}+\beta_{2} X_{a i d}{ }_{i t} \\
& +\varphi_{\text {aid }_{t}}+\varepsilon_{\text {aid }} \\
& =\alpha_{i n f r a}+\beta_{1} \text { aid }_{i t}+\beta_{2} X_{\text {infra }_{i t}}+\varphi_{\text {infra }} \\
& +\varepsilon_{\text {infra }} \text { it }
\end{aligned}
$$

Data concerning GDP, GDP Growth rate, GDP per capita, and openness to trade were 5 taken from the World Bank Indicators of global development (World Development Indicators: WDI); the Investment Climate data were sourced from the International Country Risk Guide (ICRGS). 
Here X represents the vector of relevant control variables. The other terms of Equation (2) denote the determinants of aid inflows (as natural logarithms) to infrastructure. Control variables abide by the rules deduced from previous studies whereby aid funds are being allocated via including an index that reflects the need of the aid receiving country for increased investments in infrastructure (Infrastructure needs). The logarithm of GDP per capita is also commonly used as an index of the country needs. When specific infrastructure needs are accurately defined, donors may increase the aid amounts allocated to infrastructure.

In order to obtain the required data concerning the principal measures of infrastructure, we derive infrastructure needs from the normal pattern resulting from the regression of the actual infrastructure index on per capita income, the size of population (number of inhabitants) and the geographical region.

Table D in the study Appendix displays these regressions both in the case of our inclusive infrastructure index and in the case of the four subsidiary indexes, based on the aggregate annual data of the study period. The specific aid needs of infrastructure (infrastructure needs) are subsequently determined via comparing the expected infrastructure level - as compatible with per capita income, the size of population and the area of country $i$ in the year $t$ - with the actual infrastructure index of the country in the same year. We assume that the specific aid needs of the infrastructure equal zero when the actual infrastructure index is greater or equal to the expected value of the normal pattern. Inversely, when the actual infrastructure index is smaller than the expected value, we take the absolute deviation from the normal pattern as a measure of infrastructure needs. That is to say that the higher is the expected value standing above the actual index, the higher are the aid needs of the infrastructure and vice-versa. Given that the calculated index of infrastructure needs may support the probability that a country institutionally more 
efficient receives more aid, a complex index of Governance Infrastructure has been established. It is composed of six indexes: Control of Corruption, Rule of Law, Regulatory Quality, Government Effectiveness, Political Stability and Absence of Terrorism/ Violence, and Voice and Accountability, following the methodology applied in the study of Globerman and Shapiro (2002). The Governance Infrastructure index reflects the strength of institutions in the aid receiving country. Donors should give more aid to the countries having stronger institutions so that aid can be more effective.

The Population (natural logarithm) variable is included since countries of higher population density tend to receive bigger aid amounts. The natural logarithm of aid funds allocated to other sectors than infrastructure (other aid) is also included to account for the complementary nature of various aid categories.

In Equation (3), our infrastructure index is the dependent variable. Aid is the explanatory variable of major importance to this study as it helps us to assess whether or not aid applied to infrastructure actually enhances the quality and characteristics of infrastructure in the receiving country. The $\mathrm{x}_{\text {infra }}$ vector includes aid to other sectors than infrastructure, GDP per capita, population size and country area, as control variables. GDP per capita and population size are standard elements in the relevant literature because of their impact on both the demand for infrastructure and the cost of providing it (Vijil, M. and Wagner, L. 2012; and Canning, D. 1998). The country area is also commonly taken in consideration because it is more difficult to provide an efficient infrastructure in remote regions of vast countries. We can now re-write the simultaneous Equations (1) to (3) of our model in full detail as displayed in the following Equations (4) to (6). 
aid $_{i t}=\alpha_{0}+\alpha_{1} G D P_{C_{i t}}+\alpha_{2}$ Population $_{i t}$

$+\alpha_{3}$ infrastructure needs $s_{i t}$

$+\alpha_{4}$ Governance infrastructure $_{i t}+\varphi_{\text {aid }}$

$+\varepsilon_{\text {aid }}$ it

infrast.it

$=\mu_{0}+\mu_{1}$ aid $_{i t}+\mu_{2} G D P_{C_{i t}}+\mu_{3}$ Population $_{i t}+\mu_{4}$ Area $_{i t}$

$+\varphi_{\text {infra }}$

$+\varepsilon_{\text {infra }}{ }_{i t}$

Equations (4) to (6) will be simultaneously estimated using the three-stages least squares (3SLS) method which allows us to explicitly measure dependencies between the three structural equations.

Table $\mathrm{A}$ in the Appendix includes a definition of the used variables and their data sources. A simple description of the study variables is presented in Table B. Countries of the study sample are classified by income level, according to the World Bank specifications, in Table C. Finally, the results of the calculated infrastructure needs index are listed in Table D.

\section{Results of the econometric analysis}

\subsection{Baseline estimations}

Table (1) below shows the results of our baseline estimations; two different ways of estimation according to the 3SLS method were applied to the above-mentioned study model. In columns (1) to (3) of Table (1), aid amounts allocated to sectors other than infrastructure (other aid) are deducted. These (other aid) amounts are subsequently added in the three equations, leading to the results shown in columns (4) to (6) of Table (1).

Table (1): Baseline regression results 


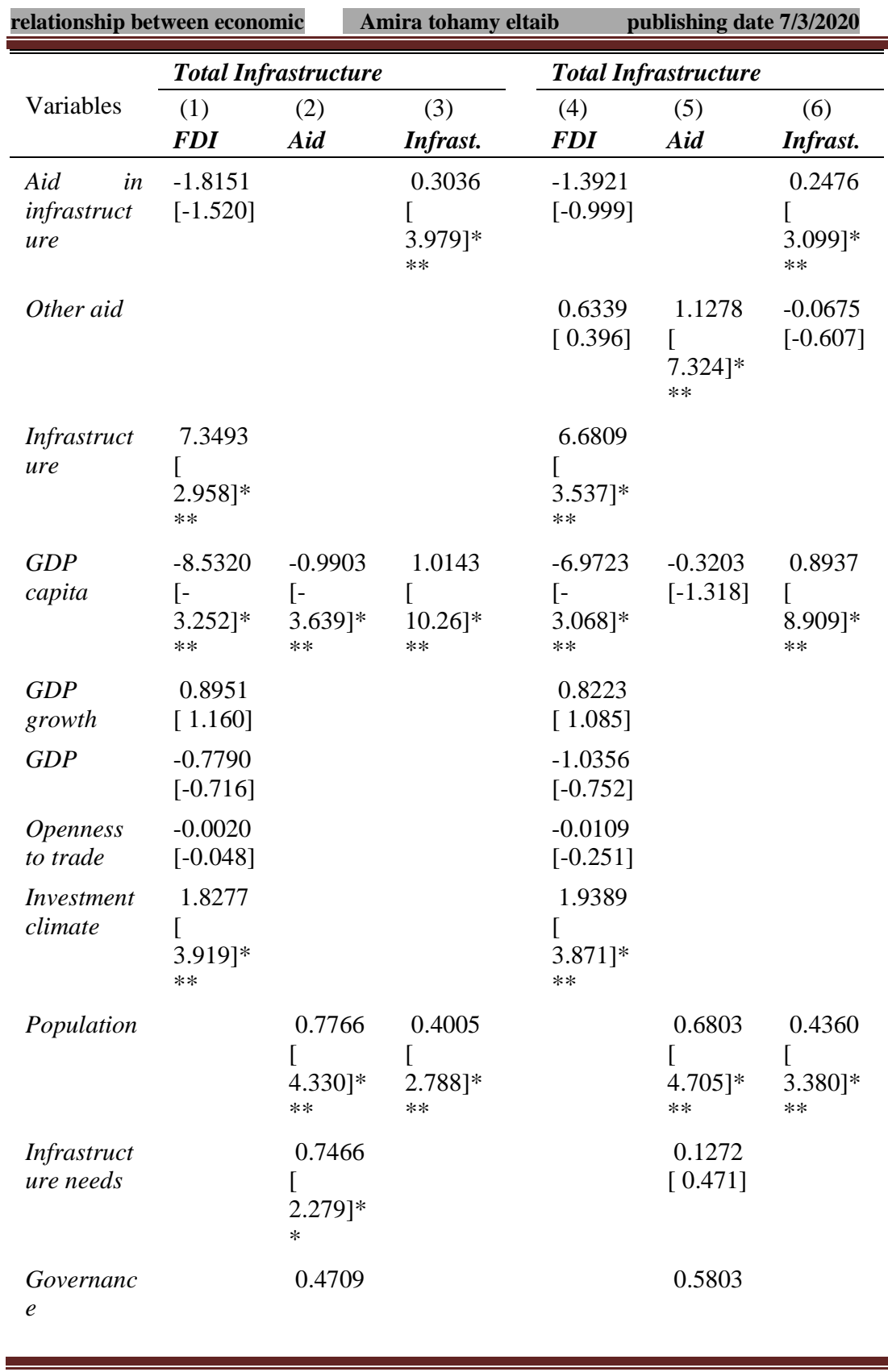




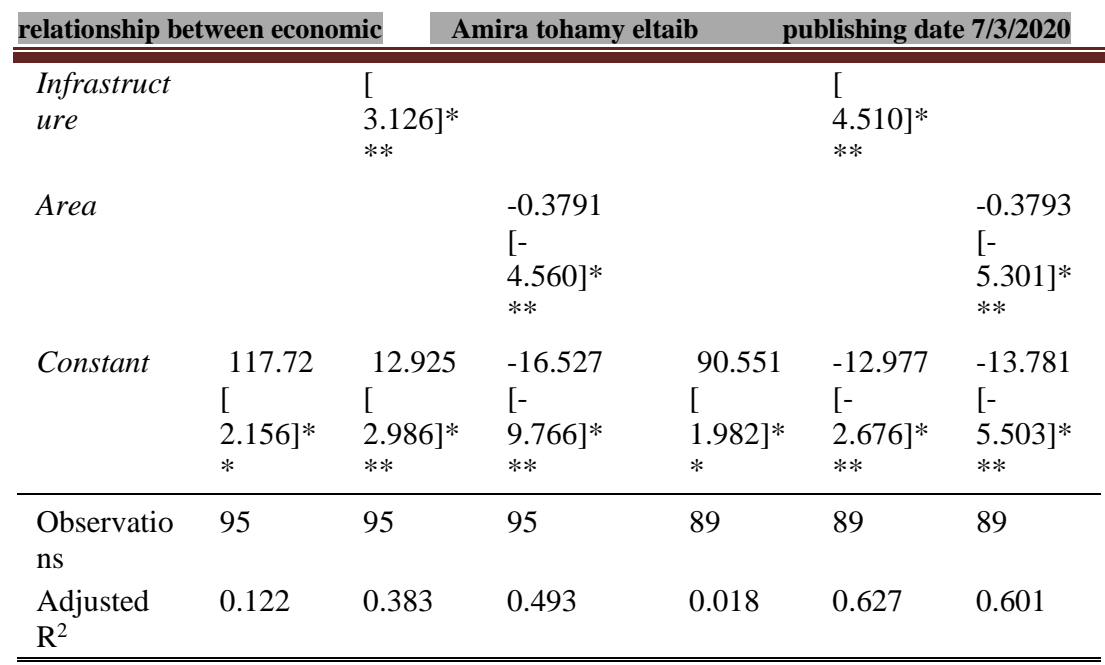

Note: $* * *, * * *$,indicate statistical significance at the level of $1 \%$, $5 \%$ and $10 \%$ respectively.

The estimated results of Infrastructure taken as the dependent variable, as seen in columns (3) and (6), show that other aid had no effect on the characteristics of the economic infrastructure in the aid-receiving MENA countries. Moreover, in conformity with the results of previous studies such as Canning, D. (1998) and Vijil and Wagner (2012), the standard of infrastructure is much better in MENA countries with a higher income level (GDP per capita), a bigger Population and a smaller Area. Taking the coefficients in column (3) at their real value, we notice that an increase of $1 \%$ in GDP per capita is associated with an almost equal improvement of 1.04 points in our inclusive infrastructure index. Similarly, an increase of $1 \%$ in Population and a decrease of $1 \%$ in Area lead to an improvement of 0.4 and 0.38 point respectively in the infrastructure index.

The most exciting result in this context is that aid allocated to infrastructure (aid in infrastructure) seems to be effective in improving the level and quality of infrastructure in aid-receiving MENA countries. This result is in agreement with the findings of Vijil and Wagner (2012). Thus we find that the coefficient of aid 
invested in infrastructure is significant at the level of $1 \%$. Quantitatively, an increase of $1 \%$ in aid in infrastructure corresponds to an improvement of 0.304 point in the Infrastructure level, as shown in column (3) of Table (1). This effect is slightly reduced when other aid is taken into account, in column (6). More importantly, and in obvious contrast with the impact of aid in infrastructure, other aid has no effect on infrastructure characteristics in MENA countries.

Moving to the estimation results of the equation of aid taken as the dependent variable as displayed in columns (2) and (5), we find that aid in infrastructure is not only effective but that it also targets the needs of the aid-receiving MENA countries. Hence, both the GDP per capita and Infrastructure needs indexes - both commonly used to measure general needs besides specific infrastructure needs - are proven significant at the $1 \%$ level as seen in column (2). The coefficient of Infrastructure needs in column (2) indicates that aid in infrastructure increases by $7.4 \%$ when the gap between expected and actual infrastructure becomes equal to ten points on our calculated Infrastructure needs index. Although modest, this result is not negligible. Furthermore, the coefficient of GDP per capita index is negative and significant at the $1 \%$ level, as shown in column (2). This result is also relevant from the quantitative point of view; as an increase of $1 \%$ in individual income reduces the inflows of aid in infrastructure by the same ratio approximately. However, it seems that the impact of the GDP per capita and Infrastructure needs indexes vanishes when other aid is included in the control variables, in column (5). Generally speaking, the results of the equations of Infrastructure and Aid taken as dependent variables reveal that aid in infrastructure is effective and is allocated to the MENA countries in dire need for such aid.

Moreover, results underscore that aid allocated to infrastructure is positively influenced by the standard of rational governance. 
Governance infrastructure has a strong positive effect on aid in infrastructure since an increase of one point in rational governance leads to an increase of 0.47 to 0.58 in the logarithm of aid in infrastructure as apparent in columns (2) and (5). This finding may be surprising, considering the wide-range controversy aroused in previous literature about the importance of rational governance in aid-receiving countries for increasing aid allocation to infrastructure; although some modern analyses of aid allocation point out to the increasing selectivity of donor countries based on the policies and institutions of the beneficiaries. [See for example: Claessens, S. et al (2009) and Dollar, D. and Levin, V. (2006)]. However, the effect of rational governance on aid seems strongly dependent on the specific governance aspect under examination. In addition, the positive coefficient of other aid reflects the positive impact of this variable on aid in infrastructure - as apparent in column (5) - and reveals the existence of an especially strong complementary relationship between aid invested in different sectors, with an elasticity equal to 1.13 .

If we now move to the equation of foreign direct investment as the dependent variable, we find the results of control variables reasonable, in most cases. The coefficient of GDP per capita, as seen in columns (1) and (4) of Table 1, is negative and significant at $1 \%$; thus denoting that the increase of income over time in the MENA hosting countries, and the increase of related costs, tend to discourage the inflows of foreign direct investment. Surprisingly, the highest rate of economic growth in the MENA countries is not associated with increasing inflows of foreign direct investment since the effect of the GDP growth variable is found insignificant. Conversely, our expectations concerning other relationships seem correct as results indicate that inflows of foreign direct investment actually increase when the investment climate of the receiving country is improved. On the other hand, 
we note that the coefficient of GDP is negative and insignificant; which can be explained by the fact that foreign direct investment, as the independent variable, is determined as a percentage of the GDP of the hosting country. Finally, the variance of the Openness to trade variable is relatively small in comparison with the variance across the hosting countries. Therefore, the effect of this last variable appears statistically insignificant.

A more exciting finding is that our composite infrastructure index which is the most important explanatory variable in the present study, is proven positive and significant at the $1 \%$ level - as seen in columns (1) and (4) of Table 1. The quantitative effect of this variable is also substantial. When the coefficient of the infrastructure index is taken at its real value, we find that an improvement of one point in the economic infrastructure of the MENA countries increases the inflows of foreign direct investment by $7.35 \%$ of the GDP of these countries. Meanwhile, aid in infrastructure has no direct effect on the inflows of foreign direct investment, as reflected by its insignificant coefficient. This result shows that aid in infrastructure is effective in boosting inflows of foreign direct investment only indirectly through influencing the level and qualities of the economic infrastructure in the host MENA countries. Given that the coefficient of aid in infrastructure is equal to approximately 0.3036, as apparent in column (3), an increase of $1 \%$ in this type of aid would increase foreign direct investment by about $2.23 \%$ on average through the channel of infrastructure.

More generally speaking, E. Mayer (2006) contends that aidrelated obligations may play an important role from the viewpoint of foreign investors who might be convinced that aid-financed infrastructure will serve them better than locally-financed infrastructure, whether because aid-financed infrastructure is expected to focus more intensively on the needs of foreign 
investments and/or enjoy higher quality or better maintenance under the external supervision of aid implementation projects.

In column (4), we can see that the coefficient of other aid is statistically insignificant. We conclude that only aid in infrastructure is influential in boosting foreign direct investment inflows through improving the characteristics of the economic infrastructure in host countries.

\subsection{Robustness and disaggregation}

In this section, we carry out three different procedures to test the robustness of the results displayed in section 4.1 above. To start with, we use two alternative measuring methods. As we cannot exclude the probability that the above-mentioned 3SLS results are erroneous due the misspecification of the baseline equations, therefore we estimate the variables of the individual equation as a robustness test. We specifically present the estimations of the System-GMM and 2SLS-IV methods in the following Table 2. Although the specifications of these later estimations are closely similar to the specifications of the baseline as described in column (1) of Table 1, we can still perceive some crucial differences. Notably, while the GMM method depends essentially on endogenous variables, the 2SLS method depends on exogenous variables.

$\underline{\text { Table 2: Regression results using GMM and 2SLS estimations }}$

\begin{tabular}{lll}
\hline \hline & $(7)$ & $(8)$ \\
Variables & SYS- & 2SLS \\
& GMM & FDI \\
\hline Aid in infrastructure & -0.5249 & -1.0262 \\
Infrastructure & {$[-0.617]$} & {$[-1.132]$} \\
& 4.576 & 6.3673 \\
GDP capita & {[} & {[} \\
\hline \hline
\end{tabular}




\begin{tabular}{llc} 
relationship between economic & Amira tohamy eltaib & publishing date 7/3/2020 \\
\hline \hline & {$[-$} & {$[-$} \\
GDP growth & $5.499]^{* * *}$ & $8.703]^{* * *}$ \\
& 0.3179 & 0.1057 \\
GDP & {[} & {[} \\
& $2.779]^{* * *}$ & $2.132]^{* *}$ \\
Openness to trade & -2.1532 & -2.1091 \\
& {$[-$} & {$[-$} \\
Investment climate & $2.139]^{* *}$ & $2.022]^{* *}$ \\
& -0.0439 & -0.0485 \\
Constant & {$[-1.044]$} & {$[-1.067]$} \\
& 1.5091 & 1.6862 \\
& {$[1.670]^{*}$} & {[} \\
& & $2.324]^{* *}$ \\
Observations & 105.69 & 122.77 \\
Number of countries & {[} & {[} \\
Number of instruments & $7.577]^{* * *}$ & $10.66]^{* * *}$ \\
Adjusted $\mathrm{R}^{2}$ & 85 & 101 \\
\hline N.B.: *******indicate & 12 & 14 \\
\hline
\end{tabular}
$10 \%$ respectively.

- The exogenous variables used in the 2SLS method include: GDP per capita, Economic growth, GDP, Openness to trade, Investment climate, Governance infrastructure, Population and Country Area.

- The endogenous variables used in the GMM method include, in addition to the exogenous variables used in the 2SLS method, the following variables: Mean years of schooling, life expectancy at birth, human development index, real wealth per capita, and real wealth as a ratio of gross national product (GNP).

Focusing on our main points of interest, we notice that the indirect effect of aid in infrastructure on foreign direct investment via Infrastructure is still valid according to our alternative estimations. Similarly, aid in infrastructure has no direct effect 
on the inflows of foreign direct investment according to the GMM and the 2SLS methods. Globally speaking, the 3SLS method seems to be the most adequate procedures for tackling the issue at hand, in view of the shortcomings of the alternative methods. One major problem facing these alternative methods is the selection of the right exogenous variables. When we discuss the exogenous variables used in the best writings with the biggest contribution to the subject of aid impact on economic growth, we deduce that all those analyses raise question marks about the validity and robustness of the chosen variables for expressing the assumed relationship. In fact, better research methods are needed to investigate the relationship between aid, infrastructure and inflows of foreign direct investment.

Therefore, we go back to the 3SLS method which is the preferred procedure for carrying out all the subsequent robustness tests. In the next step, we re-estimate the baseline equation, with all the independent variables lagged by one year $(t-1)$ in line with the study of Donaubauer et al. (2015b). In this way, we underscore the fact that most investment decisions were made based on the conditions prevailing in host countries the year before. Economic conditions prevailing in the current year represent investors' expectations concerning such conditions and have been treated in the previous section.

Table 3: Baseline estimations using one-year lagged independent variables

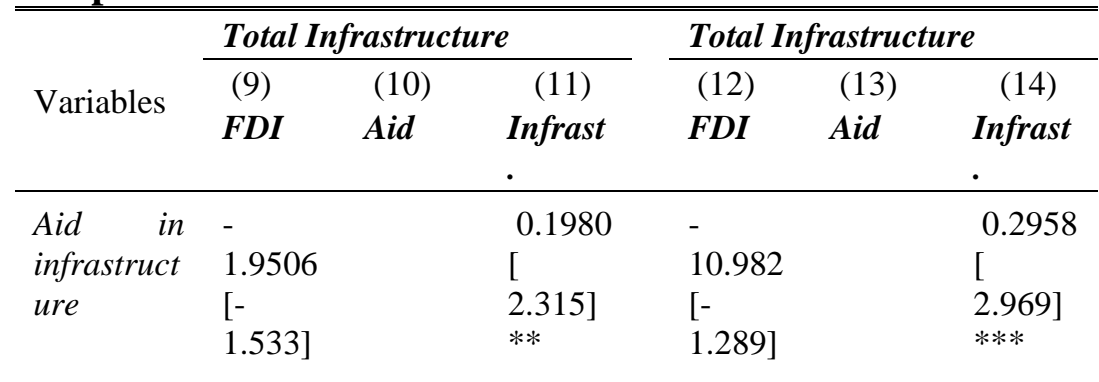




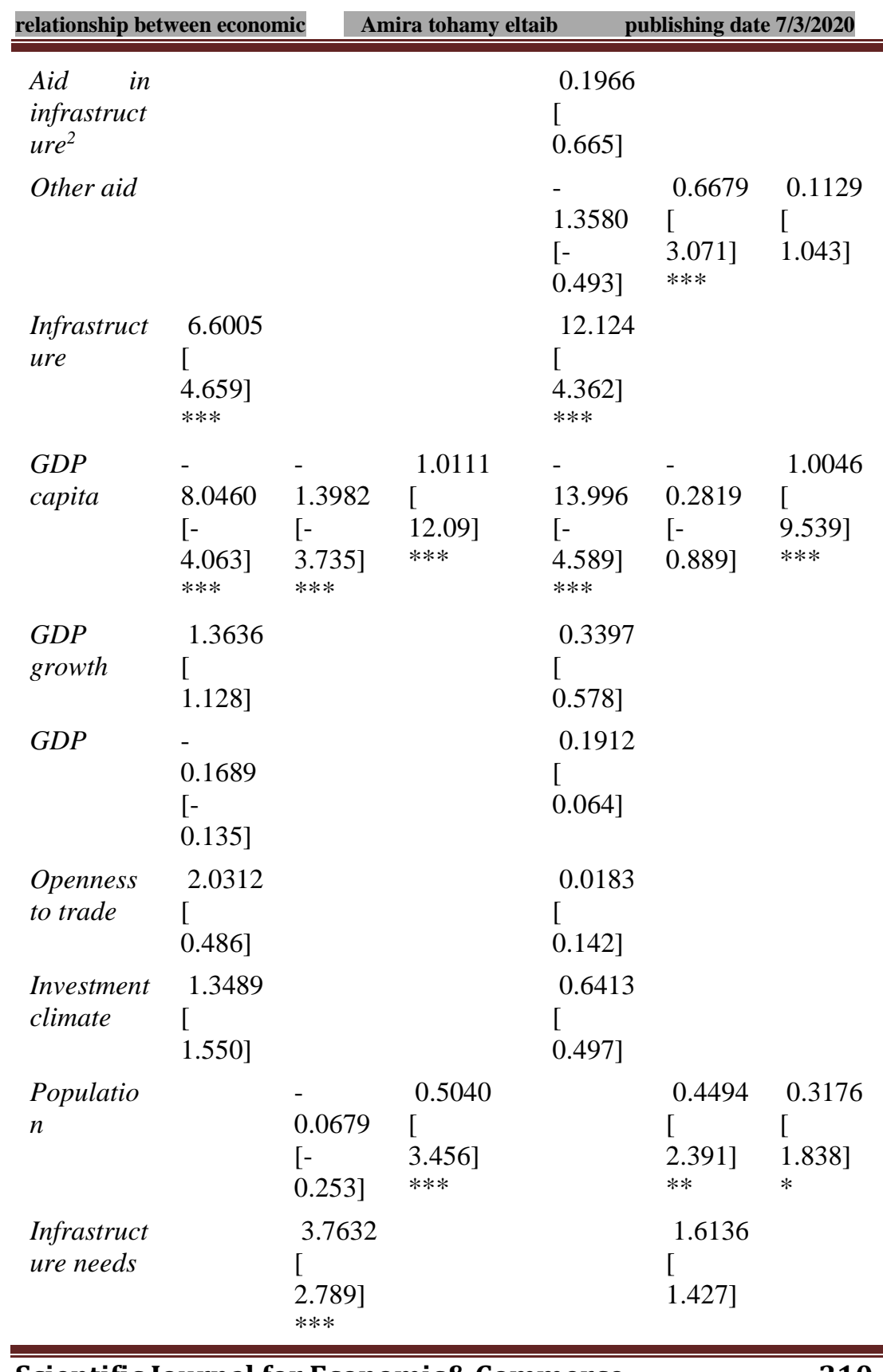




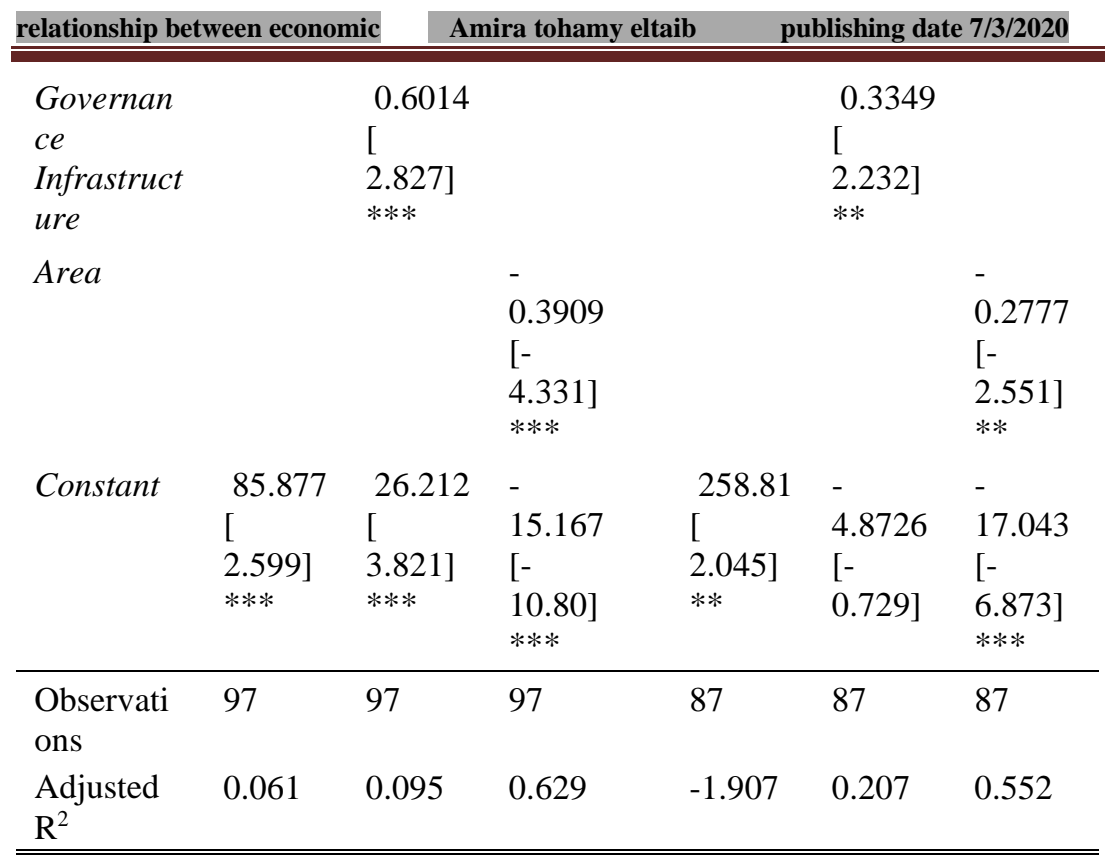

N.B.: ***,**** indicate significance at the level of $1 \%, 5 \%$ and $10 \%$ respectively.

From Table 3, we deduce that most of the control variables do not provide any additional evidences or new perspectives. Therefore, in this study, we will concentrate on aid and infrastructure as the variables of utmost importance, since results prove that our assumed relationships are in fact robust and stable to a great extent. We can notice the positive effect of aid in infrastructure on the infrastructure characteristics in the MENA countries. Moreover, Infrastructure has a strong positive effect on the inflows of foreign direct investment; while aid in infrastructure has only an indirect effect on the inflows of foreign direct investment through the channel of Infrastructure. It is noteworthy that the effect of Infrastructure on the inflows of foreign direct investment doubles when other aid is controlled. As a last procedure, we shed the light in Table 4 on aid in infrastructure and infrastructure characteristics in the MENA 
host countries. For this purpose, our inclusive infrastructure index is replaced by four infrastructure components namely infrastructure in the sectors of transport, information and communications technology, energy, and finance. Total aid in infrastructure (Code: CRS 200) is therefore substituted by its subcategories concerning: Transport and storage (210), communications (220), energy (230), and finance (240).

The results displayed in Table 4 confirm that most of the control variables do not offer any additional evidences; therefore we will focus on the most important variables in this study, namely aid and infrastructure. Results also prove that infrastructure as a determinant of foreign direct investment has a robust and rather stable effect. The subsidiary infrastructure indexes reflect a positive effect in the four foreign direct investment equations (columns 15, 18, 21, and 24). However the subsidiary infrastructure of the communications and information technology (ICT) sector has a much stronger effect on FDI; whereas the effect of infrastructure in the energy sector appears more modest, both in terms of statistical significance and quantitative impact. The relatively weak evidence concerning this later sector may be attributed to measuring problems, especially the difficulty of obtaining reliable data regarding the supply of energy. Besides, foreign direct investment may interact less with the improved infrastructure of energy-rich host countries, due to the still rather strict restrictions imposed on foreign direct investment. 


\begin{tabular}{|c|c|c|c|c|c|c|c|c|c|c|c|c|}
\hline \multirow[b]{2}{*}{ Variables } & \multicolumn{3}{|c|}{ Transport Infrastructure } & \multicolumn{3}{|c|}{ ICT Infrastructure } & \multicolumn{2}{|c|}{$\begin{array}{l}\text { Bank \& } \\
\text { Infrastructure }\end{array}$} & \multirow{2}{*}{$\begin{array}{c}\text { Finance } \\
(23) \\
\text { Infrast }\end{array}$} & \multicolumn{3}{|c|}{ Energy Infrastructure } \\
\hline & $\begin{array}{r}(15) \\
F D I\end{array}$ & $\begin{array}{l}\text { (16) } \\
\text { Aid }\end{array}$ & $\begin{array}{c}(17) \\
\text { Infrast } \\
\end{array}$ & $\begin{array}{l}(18) \\
F D I\end{array}$ & $\begin{array}{l}(19) \\
\text { Aid }\end{array}$ & $\begin{array}{c}(20) \\
\text { Infrast } \\
\text {. }\end{array}$ & $\begin{array}{r}(21) \\
F D I\end{array}$ & $\begin{array}{l}(22) \\
\text { Aid }\end{array}$ & & $\begin{array}{r}(24) \\
\text { FDI }\end{array}$ & $\begin{array}{l}(25) \\
\text { Aid }\end{array}$ & $\begin{array}{l}\text { (26) } \\
\text { Infrast } \\
\text {. }\end{array}$ \\
\hline $\begin{array}{l}\text { Aid in } \\
\text { infrastruct } \\
\text { ure }\end{array}$ & $\begin{array}{l}- \\
0.5240 \\
{[-} \\
0.986]\end{array}$ & & $\begin{array}{l}0.1379 \\
{[} \\
4.139] \\
* * *\end{array}$ & $\begin{array}{l}- \\
2.7179 \\
{[-} \\
1.523]\end{array}$ & & $\begin{array}{l}0.1362 \\
{[} \\
1.701] \\
*\end{array}$ & $\begin{array}{l}- \\
0.7298 \\
{[-} \\
1.418]\end{array}$ & & $\begin{array}{l}0.7824 \\
{[} \\
7.742] \\
* * *\end{array}$ & $\begin{array}{l}0.214 \\
6 \\
{[} \\
1.152]\end{array}$ & & $\begin{array}{l}- \\
1.4521 \\
{[-} \\
1.903] \\
*\end{array}$ \\
\hline $\begin{array}{l}\text { Aid in } \\
\text { infrastruct } \\
\text { ure }^{2}\end{array}$ & & & & & & & & & & & & $\begin{array}{l}0.0475 \\
{[} \\
1.919] \\
*\end{array}$ \\
\hline Infrastruct & & & & & & & & & & & & \\
\hline ure & $\begin{array}{l}5.8405 \\
{[} \\
3.093] \\
* * *\end{array}$ & & & $\begin{array}{l}14.751 \\
{[} \\
2.404] \\
* *\end{array}$ & & & $\begin{array}{l}4.9915 \\
{[} \\
5.883] \\
* * *\end{array}$ & & & $\begin{array}{l}2.381 \\
8 \\
{[} \\
1.862] \\
*\end{array}$ & & \\
\hline$G D P$ & - & - & & - & - & & - & & - & - & - & \\
\hline capita & $\begin{array}{l}3.2499 \\
{[-} \\
2.684] \\
* * *\end{array}$ & $\begin{array}{l}1.5612 \\
{[-} \\
4.814] \\
* * *\end{array}$ & $\begin{array}{l}1.0316 \\
{[} \\
10.54] \\
* * *\end{array}$ & $\begin{array}{l}16.025 \\
{[-} \\
2.336] \\
* *\end{array}$ & $\begin{array}{l}0.5222 \\
{[-} \\
2.507]\end{array}$ & $\begin{array}{l}0.9328 \\
{[} \\
11.66] \\
* * *\end{array}$ & $\begin{array}{l}6.6583 \\
{[-} \\
4.368] \\
* * *\end{array}$ & $\begin{array}{l}0.1073 \\
{[} \\
0.241]\end{array}$ & $\begin{array}{l}0.2673 \\
{[-} \\
1.226]\end{array}$ & $\begin{array}{l}1.000 \\
9 \\
{[-} \\
0.925]\end{array}$ & $\begin{array}{l}1.6276 \\
{[-} \\
4.061] \\
* * *\end{array}$ & $\begin{array}{l}0.3867 \\
{[} \\
3.630] \\
* * *\end{array}$ \\
\hline
\end{tabular}




\begin{tabular}{|c|c|c|c|c|c|c|c|c|c|c|c|c|}
\hline$G D P$ & - & & & & & & & & & & & \\
\hline growth & $\begin{array}{l}0.1509 \\
{[-} \\
0.211]\end{array}$ & & & $\begin{array}{l}2.8215 \\
{[} \\
1.375]\end{array}$ & & & $\begin{array}{l}1.4439 \\
{[} \\
2.314] \\
* *\end{array}$ & & & $\begin{array}{l}0.031 \\
3 \\
{[} \\
0.045]\end{array}$ & & \\
\hline$G D P$ & $\begin{array}{l}- \\
4.2207 \\
{[-} \\
2.869] \\
* * *\end{array}$ & & & $\begin{array}{l}- \\
1.0270 \\
{[-} \\
1.211]\end{array}$ & & & $\begin{array}{l}3.1906 \\
{[} \\
1.972] \\
* *\end{array}$ & & & $\begin{array}{l}- \\
1.315 \\
9 \\
{[-} \\
1.345]\end{array}$ & & \\
\hline $\begin{array}{l}\text { Openness } \\
\text { to trade }\end{array}$ & $\begin{array}{l}0.0288 \\
{[} \\
1.138]\end{array}$ & & & $\begin{array}{l}2.3192 \\
{[} \\
1.064]\end{array}$ & & & $\begin{array}{l}- \\
0.0692 \\
{[-} \\
1.747] \\
*\end{array}$ & & & $\begin{array}{l}0.033 \\
1 \\
{[} \\
0.947]\end{array}$ & & \\
\hline $\begin{array}{l}\text { Investmen } \\
\text { t climate }\end{array}$ & $\begin{array}{l}1.1164 \\
{[} \\
3.083] \\
* * *\end{array}$ & & & $\begin{array}{l}3.0905 \\
{[} \\
2.619] \\
* * *\end{array}$ & & & $\begin{array}{l}1.3979 \\
{[} \\
2.932] \\
* * *\end{array}$ & & & $\begin{array}{l}0.866 \\
9 \\
{[} \\
2.064] \\
* *\end{array}$ & & \\
\hline $\begin{array}{l}\text { Populatio } \\
n\end{array}$ & & $\begin{array}{l}0.4119 \\
{[} \\
1.991] \\
* *\end{array}$ & $\begin{array}{l}1.0025 \\
{[} \\
10.53] \\
* * *\end{array}$ & & $\begin{array}{l}0.4369 \\
{[} \\
2.925] \\
* * *\end{array}$ & $\begin{array}{l}0.4251 \\
{[} \\
3.919] \\
* * *\end{array}$ & & $\begin{array}{l}0.6020 \\
{[} \\
1.852] \\
*\end{array}$ & $\begin{array}{l}- \\
1.9980 \\
{[-} \\
5.810] \\
* * *\end{array}$ & & $\begin{array}{l}- \\
0.4985 \\
{[-} \\
1.454]\end{array}$ & $\begin{array}{l}0.7098 \\
{[} \\
6.831] \\
* * *\end{array}$ \\
\hline $\begin{array}{l}\text { Infrastruct } \\
\text { ure needs }\end{array}$ & & $\begin{array}{l}- \\
1.4266\end{array}$ & & & $\begin{array}{l}- \\
0.1029\end{array}$ & & & 0.0529 & & & 1.0191 & \\
\hline
\end{tabular}




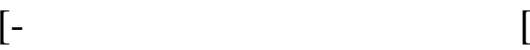

4.887]

0.273

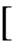

$* * *$

$0.273]$

$0.071]$

$1.531]$

Governan

ce
Infrastruct

ure

1.2816
[
$8.543]$
$* * *$

0.2286

0.7738

0.7693

[

$2.523]$

$* *$
3.384]

$* * *$
[

2.847]

$* * *$

Area

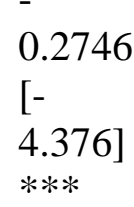

0.1120

0.7098

[-

[

3.919

$[-$

6.029]

***

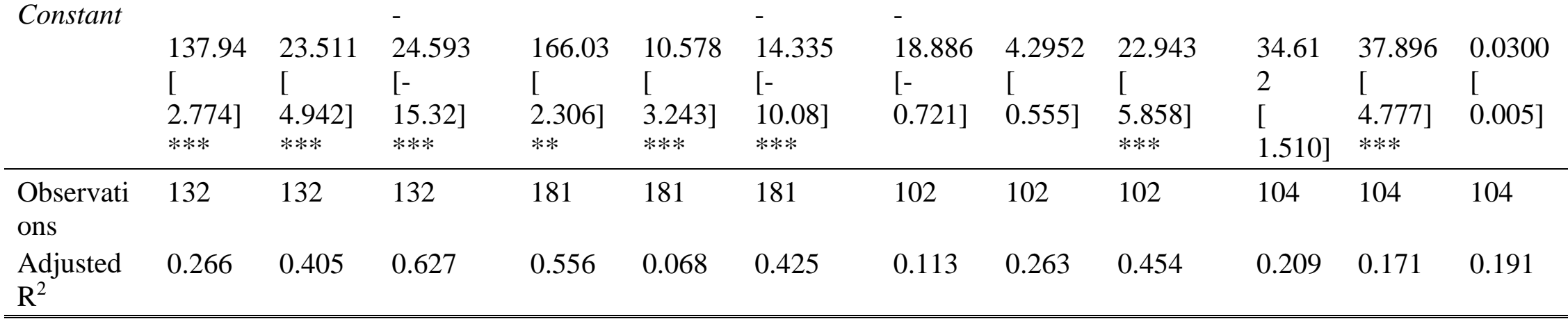

N.B.: $* * * * * * *$ indicate significance at the level of $1 \%, 5 \%$ and $10 \%$ respectively. 
Although infrastructure in general has an important influence on foreign direct investment, three out of four subcategories of aid in infrastructure encourage the inflows of foreign direct investment via the channel of infrastructure, specifically in the corresponding sectors of transport, communications and information technology, and finance. The exception lies in aid in infrastructure of the energy sector and the corresponding channel of energy production and consumption. The effect of aid in infrastructure of the energy sector on the infrastructure of that sector is not linear but $U$ shaped, indicating that this effect is negative at the lower aid levels but becomes positive at higher levels, starting from the $10 \%$ aid level. It is noteworthy that aid in infrastructure of the energy sector contributed less than $15 \%$ of aid in infrastructure throughout the study period. Therefore, annual fluctuations in aid inflows tended to be relatively large in that sector. From the quantitative point of view, aid in infrastructure of the two sectors of communications and finance had the greatest effect in indirectly encouraging the inflows of foreign direct investment due to the improvement of infrastructure characteristics in these two sectors in the MENA countries. Conversely, the indirect effect of aid in infrastructure of the transport sector does not seem to benefit much the needy host countries. Estimation results in column 16 underscore that aid allocation to the infrastructure of the transport sector is biased against those who need it most. Finally, Table 4 indicates the absence of direct effects of the four subcategories of aid in infrastructure on foreign direct investment taken as the dependent variable.

\section{Conclusion}

This study endeavors to analyze the interaction between aid in infrastructure and the actual infrastructure level, on one hand, and the impact of that interaction on foreign direct investment in the MENA countries, on the other hand. Using the simultaneous equations model and the three stages least squares (3SLS) 
method, the study reveals a strong positive effect of infrastructure on foreign direct investment. An increase of one point on the index of economic infrastructure leads to an increase of 6 to $7 \%$ of GDP in the inflows of foreign direct investment to the MENA countries. Moreover, the results of robustness tests and disaggregation analyses are compatible with the baseline estimations thus proving that such effect is constant and stable.

Another important finding is that aid in infrastructure has only an indirect effect on foreign direct investment through the channel of the actual infrastructure level. Aid in infrastructure has a positive effect on infrastructure. In other words, aid in infrastructure is effective for improving the level and quality of the economic infrastructure of the aid-receiving MENA countries.

Constant inflows of aid in infrastructure can influence infrastructure in two ways. The first way is through improving infrastructure flow indexes; such as increasing the supply and consumption of electricity; or increasing transport capacity, in terms of passengers and cargo transport. The second way is through helping to maintain the current stock such as seaports and communications networks.

At the sectors' level, there is evidence that infrastructure of the communications and information technology sector has the greatest effect on attracting foreign direct investment to the MENA countries, remotely followed by the infrastructure of the transport sector, then by the infrastructure of the finance sector. Finally the infrastructure of the energy sector has the least impact on attracting FDI inflows.

To sum up, this study proves the existence of a positive interaction between aid in infrastructure and the actual infrastructure level. Together with an adequate investment climate and other advantageous factors, aid in infrastructure can induce foreign investors to pump more of their investment funds in the MENA countries. 


\section{References}

Ahmad, N.A, Ismail , N.W.\& Nordin,N.H.(2015), The Impact of Infrastructure on Foreign Direct Investment in Malaysia, International Journal of Management Excellence, Vol. 5, No. 1. Asiedu ,E. , (2002) ,On the determinants of foreign direct investment to developing countries : Is Africa Different, World Development ,Vol.30,No.1,pp.107-119

Bakar ,A.N.A.,Mat ,S.H.C. \& Harun ,M.(2012), The impact of infrastructure on forgeing direct investment : The case of Malysia , Procedia - Social and Behavioral Sciences 65, 205 - 211

Canning, D. (1998). A database of world stocks of infrastructure, 1950-95. The World Bank Economic Review, 12(3), 529-547.

Claessens, S., Cassimon, D., \& van Campenhout, B. (2009). Evidence on changes in aid allocation criteria. World Bank Economic Review, 23(2),185-208.

Dollar, D., \& Levin, V. (2006). The increasing selectivity of foreign aid, 1984-2003. World Development,Vol.34,No. 12, 2034-2046.

Donaubauer, J., Meyer, B. E., \& Nunnenkamp, P. (2016). A new global index of infrastructure: Construction, rankings and applications. The World Economy, 39(2), 236-259.

Donaubauer, J., Meyer, B., \& Nunnenkamp, P. (2015). Aid, infrastructure, and FDI: Assessing the transmission channel with a new index of infrastructure. World Development, 78, 230-245.

Globerman, S., \& Shapiro, D. (2002). Global foreign direct investment flows: The role of governance infrastructure. World development, 30(11), 1899-1919.

Globerman,S.,Shapiro,D.(2003), Governance infrastructure and US foreign direct investment, Journal of International Business Studies (2003) 34, 19-39

Khadaroo,A.J. and Seetanah ,B.(2010) ' Transport infrastructure and foreign direct investment, Journal of International Development, No.22, 103-123 
Kirkpatrick, C. ,Parker ,D. \& Zhang, Y.F. (2004), Foreign direct investment in infrastructure in developing countries : Dose regulation make a difference?, Centre on Regulation and Competition Working Paper Series, No. 85.

Loree DW, Guisinger S. 1995. Policy and non-policy determinants of US equity foreign direct investment. Journal of International Business Studies 26(2):

Mayer, T. (2006). Policy coherence for development: A background paper on foreign direct investment. Paris: $O E C D$ Development Centre, Working Paper 253.

Ogunjimi ,J. \& Amune ,B., (2017), Impact of Infrastructure on Foreign Direct Investment in Nigeria: An Autoregressive Distirbuted Lag (ARDL) Approach, MPRA Paper No. 75996, posted 13 January 2017, https://mpra.ub.unimuenchen.de/75996/

Pradhana,R.P. , Normanb, N.R. , Badirc, Y.\& Samadhana ,B.(2013), Transport Infrastructure, Foreign Direct Investment and Economic Growth Interactions in India: The ARDL Bounds Testing Approach, 2nd Conference of Transportation Research Group of India (2nd CTRG), Procedia - Social and Behavioral Sciences 104 ( 2013 ) $914-921$

Quazi R. 2005. Economic Freedom and Foreign Direct Investment in East Asia, College of Business, Prairie ViewA\& MUniversity, Prairie View, Texas 77446. USA International Academy of Business and Public Administration Disciplines (IABPAD) Meetings.

Rajan, R. G., Subramanian, A. (2008). Aid and growth: what does the cross-country evidence really show? Review of Economics and Statistics, 90(4): 643-65.

Rehman,C.A., Ilyas,M., Alam,H.M \& Akram,M.(2011),The Impact of Infrastructure on Foreign Direct Investment: The Case of Pakistan, International Journal of Business and Management Vol. 6, No. 5,PP.268-276 
Richaud C, Sekkat K, Varoudakis A. 1999. Infrastructure and Growth Spillovers: A Case for a Regional Infrastructure Policy in Africa, Mimeo. University of Brussels. Morrisset P. 2000. FDI to Africa, policy matters. Mime

Sekkat K, Veganzones-Varoudakis M. 2004. Trade and Foreign Exchange Liberalisation, Investment Climate and FDI in the MENA Countries. Working Papers DULBEA, Universite' Libre de Bruxelles, Department of Applied Economics (DULBEA)

Shah,M.H.(2014), The SignifIcance Of Infrastructure For FDI Inflow In Developing countries, Journal of Life Economics 2/2014

Shapiro,D. (2002), Global Foreign Direct Investment Flows: The Role of Governance Infrastructure, World Development Vol. 30, No. 11, pp. 1899-1919

Vijil, M., \& Wagner, L. (2012). Does aid for trade enhance export performance? Investigating the infrastructure channel. The World Economy, 35(7), 838-868.

Wei,S. 2000. How taxing is corruption on international investors? ,Review of Economics and Statistics, Vol.82,No.1, 1-11.

Wheeler D, Mody A. 1992. International investment location decisions: the case of U.S. firms. Journal of International Economics 33: 57-76. 
7. Appendix

Table (A): Data definition and sources

\begin{tabular}{|c|c|c|}
\hline $\begin{array}{l}\text { Study variables } \\
\text { FDI flow ( } \% \text { of } \\
\text { GDP) }\end{array}$ & $\begin{array}{l}\text { Definition } \\
\text { Net inflows of foreign } \\
\text { direct investment as a } \\
\text { percentage of gross } \\
\text { domestic product }\end{array}$ & $\begin{array}{l}\text { Source } \\
\text { World Bank; } \\
\text { World } \\
\text { Development } \\
\text { Indicators } \\
\text { (WDI) }\end{array}$ \\
\hline $\begin{array}{l}\text { Aid in infra- } \\
\text { Structure }\end{array}$ & $\begin{array}{l}\text { Total } \\
\text { development } \begin{array}{r}\text { official } \\
\text { aid }\end{array} \\
\text { inflows in US\$ to } \\
\text { economic } \\
\text { infrastructure } \\
\text { contributed by DAC, } \\
\text { multinationals and } \\
\text { other donors; as stated } \\
\text { in the creditors } \\
\text { reporting system of } \\
\text { OECD-DAC by virtue } \\
\text { of CRS code 200 (in } \\
\text { natural logarithms) }\end{array}$ & $\begin{array}{l}\text { Statistics of } \\
\text { the } \\
\text { Development } \\
\text { Assistance } \\
\text { Committee } \\
\text { (OECD- } \\
\text { DAC) }\end{array}$ \\
\hline
\end{tabular}

\begin{tabular}{|c|c|}
\hline $\begin{array}{l}\text { Aid in } \\
\text { Transport } \\
\text { Infrastructure }\end{array}$ & $\begin{array}{l}\text { Total official } \\
\text { development aid } \\
\text { inflows in US\$ to the } \\
\text { transport sector from } \\
\text { all donors, as stated in } \\
\text { the creditors reporting } \\
\text { system of OECD-DAC } \\
\text { by virtue of CRS code } \\
210 \text { (in natural log.) }\end{array}$ \\
\hline
\end{tabular}

$\begin{array}{llr}\text { Aid in } & \text { Total } & \text { official } \\ \text { Communications } & \begin{array}{l}\text { aECD-DAC } \\ \text { development }\end{array} & \text { aid }\end{array}$




$\begin{array}{ll}\text { Infrastructure } & \text { inflows in US\$ to the } \\ \text { communications sector } \\ \text { from all donors, as } \\ \text { stated in the creditors } \\ \text { reporting system of } \\ \text { OECD-DAC by virtue } \\ \text { of CRS code } 220 \text { (in } \\ \text { natural log.) }\end{array}$

\begin{tabular}{|c|c|c|}
\hline $\begin{array}{l}\text { Aid in energy } \\
\text { infrastructure }\end{array}$ & 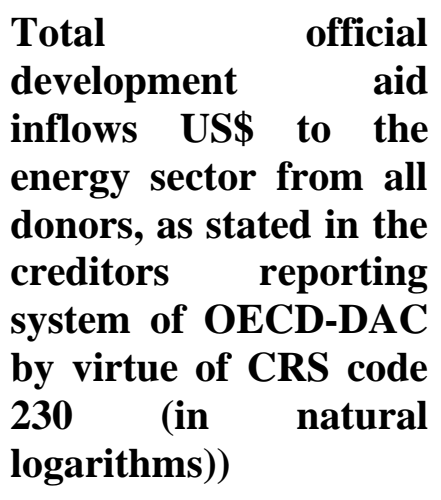 & OECD-DAC \\
\hline $\begin{array}{l}\text { Aid in financial } \\
\text { infrastructure }\end{array}$ & 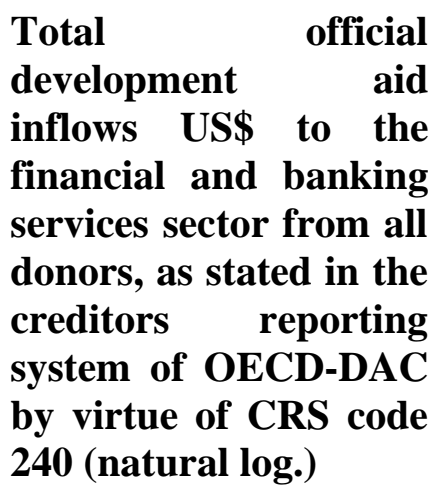 & OFCD-DAC \\
\hline Other aid & $\begin{array}{lr}\text { Total } & \text { official } \\
\text { development } & \text { aid } \\
\text { inflows in US\$ to }\end{array}$ & OECD-1 \\
\hline
\end{tabular}




\begin{tabular}{|c|c|c|}
\hline & $\begin{array}{l}\text { domains other than } \\
\text { economic } \\
\text { infrastructure from all } \\
\text { donors (natural log.) }\end{array}$ & \\
\hline Infrastructure & $\begin{array}{l}\text { First } \\
\text { component in four } \\
\text { sectors: Transport, } \\
\text { Communications and } \\
\text { Information } \\
\text { Technology, Energy } \\
\text { and Finance }\end{array}$ & $\begin{array}{l}\text { Researcher's } \\
\text { calculations } \\
\text { based on } \\
\text { WDI } \\
\text { data }\end{array}$ \\
\hline $\begin{array}{l}\text { Transport } \\
\text { infrastructure }\end{array}$ & $\begin{array}{l}\text { The First Principal } \\
\text { Component of four } \\
\text { essential indexes } \\
\text { reflecting the quality of } \\
\text { the transport sector for } \\
\text { investors, namely: air } \\
\text { freight cargo (million } \\
\text { tons - km); number of } \\
\text { flights of airlines } \\
\text { recorded at the global } \\
\text { level- transport traffic } \\
\text { in containers seaports- } \\
\text { Country's seaports } \\
\text { connection to seaports } \\
\text { worldwide }\end{array}$ & $\begin{array}{l}\text { Researcher's } \\
\text { calculations } \\
\text { based on } \\
\text { WDI } \\
\text { data }\end{array}$ \\
\hline $\begin{array}{l}\text { ICT } \\
\text { infrastructure }\end{array}$ & $\begin{array}{l}\text { The First Principal } \\
\text { Component of four } \\
\text { essential indexes } \\
\text { reflecting the level of } \\
\text { available } \\
\text { infrastructure in the } \\
\text { communications sector }\end{array}$ & $\begin{array}{l}\text { Researcher's } \\
\text { calculations } \\
\text { based on } \\
\text { WDI } \\
\text { data }\end{array}$ \\
\hline
\end{tabular}

Scientific Journal for Economic\& Commerce 


\begin{tabular}{|c|c|c|}
\hline & $\begin{array}{l}\text { as determined by: } \\
\text { Number of users of } \\
\text { mobile phones, landline } \\
\text { phones, the internet, } \\
\text { and subscribers to the } \\
\text { WATS (per 100 } \\
\text { individuals) }\end{array}$ & \\
\hline $\begin{array}{l}\text { Financial } \\
\text { infrastructure }\end{array}$ & $\begin{array}{l}\text { The First Principal } \\
\text { Component of four } \\
\text { essential indexes } \\
\text { reflecting the level of } \\
\text { available } \\
\text { infrastructure for the } \\
\text { banking and financial } \\
\text { sector as represented } \\
\text { by: Banks' net interest } \\
\text { margin; private credit } \\
\text { as bank deposits/GDP; } \\
\text { number of bank } \\
\text { branches per } 100 \\
\text { thousand adults; } \\
\text { banks' Z-index. }\end{array}$ & $\begin{array}{l}\text { Researcher's } \\
\text { calculations } \\
\text { based on } \\
\text { WDI } \\
\text { data }\end{array}$ \\
\hline $\begin{array}{l}\text { Energy } \\
\text { infrastructure }\end{array}$ & $\begin{array}{l}\text { The First Principal } \\
\text { Component of three } \\
\text { essential indexes } \\
\text { reflecting the quality of } \\
\text { Infrastructure in the } \\
\text { energy sector as } \\
\text { reflected by: Electricity } \\
\text { consumption (kwh) per } \\
\text { individual; electricity } \\
\text { production (kwh); } \\
\text { wasted electrical } \\
\text { capacity during }\end{array}$ & $\begin{array}{l}\text { Researcher's } \\
\text { calculations } \\
\text { based on } \\
\text { WDI } \\
\text { data }\end{array}$ \\
\hline
\end{tabular}

Scientific Journal for Economic\& Commerce 


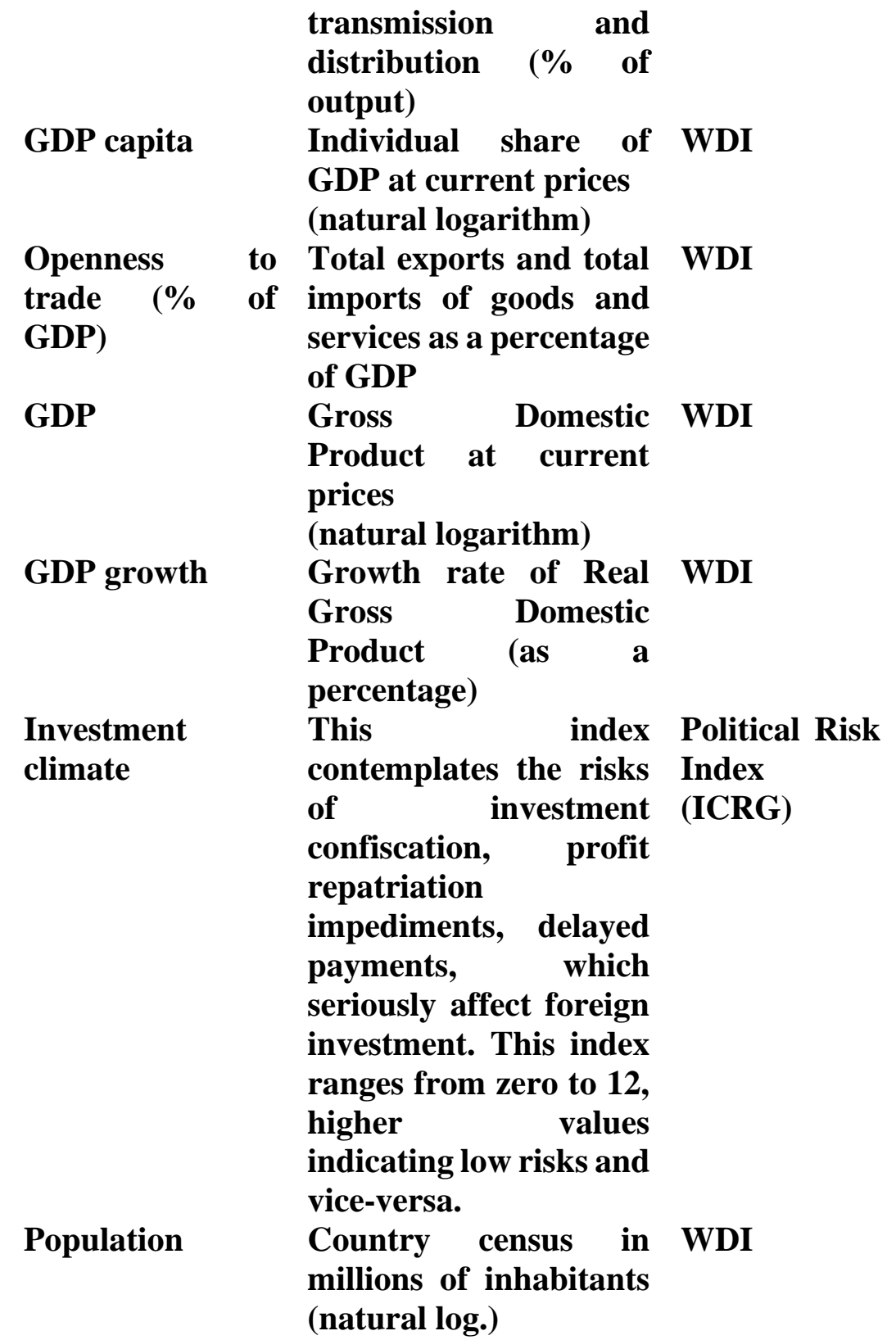

Scientific Journal for Economic\& Commerce 


\begin{tabular}{|c|c|c|}
\hline $\begin{array}{l}\text { Governance } \\
\text { Infrastructure }\end{array}$ & $\begin{array}{lr}\text { The First } & \text { Principal } \\
\text { Component } & \text { of } \\
\text { Governance } & \text { World } \\
\text { indexes: } & \text { Voicing } \\
\text { opinion } & \text { and } \\
\text { accountability; political } \\
\text { stability; government } \\
\text { effectiveness; } \\
\text { bureaucracy type; law } \\
\text { enforcement; } \\
\text { corruption control; as } \\
\text { developed r by } \\
\text { Kaufmann et al. (1999) }\end{array}$ & $\begin{array}{l}\text { Database of } \\
\text { Worldwide } \\
\text { Governance } \\
\text { Indicators } \\
\text { (WGI) of the } \\
\text { World Bank }\end{array}$ \\
\hline $\begin{array}{l}\text { Area } \\
\text { square km) }\end{array}$ & $\begin{array}{l}\text { Country area including } \\
\text { the surface of water } \\
\text { resources in square km } \\
\text { (natural log.) }\end{array}$ & WDI \\
\hline
\end{tabular}

Table (B): Summary statistics of the study variables

\begin{tabular}{|c|c|c|c|c|c|}
\hline & Obs. & Mean & $\begin{array}{l}\text { Std. } \\
\text { dev. }\end{array}$ & Min & $\operatorname{Max}$ \\
\hline FDI flow (\% of GDP) & 403 & 3.4237 & 4.492 & $-\overline{4}+3369$ & 37.166 \\
\hline $\begin{array}{l}\text { Aid in infrastructure (\$ } \\
\text { million) }\end{array}$ & 283 & 209.55 & 437.6 & 0.0034 & 2751.6 \\
\hline $\begin{array}{l}\text { Aid in transport } \\
\text { infrastructure }(\$ \text { million })\end{array}$ & 266 & 80.128 & 163.3 & $-\overline{1.6888}$ & 996.01 \\
\hline $\begin{array}{l}\text { Aid in communication } \\
\text { infrastructure }(\$ \text { million })\end{array}$ & 270 & 6.2839 & 28.99 & 0.0031 & 361.46 \\
\hline $\begin{array}{l}\text { Aid in financial } \\
\text { infrastructure }(\$ \text { million })\end{array}$ & 248 & 48.863 & 195.2 & $\begin{array}{l}3.50 \mathrm{e}- \\
5\end{array}$ & 1738.2 \\
\hline $\begin{array}{l}\text { Aid in energy infrastructure } \\
\text { (\$ million) }\end{array}$ & 255 & 85.746 & 179.5 & 0.0031 & 1475 \\
\hline
\end{tabular}




\begin{tabular}{|c|c|c|c|c|c|}
\hline relationship between economic & \multicolumn{2}{|c|}{ Amira tohamy eltaib } & \multicolumn{3}{|c|}{ publishing date $7 / 3 / 2020$} \\
\hline Other aid (\$ million) & 325 & 838.33 & 1672 & 726.65 & 20106 \\
\hline Infrastructure & 156 & $\begin{array}{l}1.08 \mathrm{e}- \\
18\end{array}$ & 1.481 & $-\overline{2.8791}$ & 3.9505 \\
\hline Transport infrastructure & 241 & $\begin{array}{l}2.76 \mathrm{e}- \\
17\end{array}$ & 1.685 & - & 7.4848 \\
\hline ICT infrastructure & 363 & $\begin{array}{l}- \\
5.63 \mathrm{e}- \\
17\end{array}$ & 1.622 & $-\overline{2.3319}$ & 5.2136 \\
\hline $\begin{array}{l}\text { Bank \& finance-related } \\
\text { infrastructure }\end{array}$ & 239 & $\begin{array}{l}2.12 \mathrm{e}- \\
16\end{array}$ & 1.519 & - & 2.7247 \\
\hline $\begin{array}{l}\text { Energy-related } \\
\text { infrastructure }\end{array}$ & 300 & $\begin{array}{l}1.24 \mathrm{e}- \\
16\end{array}$ & 1.221 & - & 2.7511 \\
\hline $\begin{array}{l}\text { Need related } \\
\text { infrastructure }\end{array}$ & & & & & \\
\hline Total infrastructure & 149 & 0.7901 & 1.565 & 0 & 100 \\
\hline Transport infrastructure & 235 & 0.8150 & 1.829 & 0 & 100 \\
\hline ICT infrastructure & 356 & 0.7549 & 1.508 & 0 & 100 \\
\hline $\begin{array}{l}\text { Bank \& finance-related } \\
\text { infrastructure }\end{array}$ & 239 & 0.3829 & 0.677 & 0 & 100 \\
\hline $\begin{array}{l}\text { Energy-related } \\
\text { infrastructure }\end{array}$ & 300 & 0.7973 & 1.628 & 0 & 100 \\
\hline GDP capita & 405 & 11859 & 15974 & 366.17 & 85076 \\
\hline GDP growth & 393 & 4.3133 & 9.034 & - & 123.14 \\
\hline$G D P(\$$ million $)$ & 405 & 13249 & 183224 & 551.23 & 950579 \\
\hline $\begin{array}{l}\text { Openness to trade (\% of } \\
\text { GDP })\end{array}$ & 394 & 82.438 & 31.19 & 19.101 & 191.88 \\
\hline Investment climate & 378 & 8.1799 & 2.293 & 2 & 11.5 \\
\hline Population (million) & 432 & 20.636 & 23.64 & 0.5925 & 96.443 \\
\hline Governance Infrastructure & 408 & $\begin{array}{l}2.13 \mathrm{e}- \\
16\end{array}$ & 2.136 & - & 4.0892 \\
\hline Area (1000 square $\mathrm{km})$ & 432 & 672.54 & 791.2 & 0.7100 & 2589 \\
\hline
\end{tabular}


Table (C): Sample data classified by income level

\begin{tabular}{|c|c|c|c|c|}
\hline \multirow{2}{*}{$\begin{array}{l}\text { Low- } \\
\text { income } \\
\text { Countries }\end{array}$} & $\begin{array}{l}\text { Middle } \\
\text { Countries }\end{array}$ & income & \multirow{2}{*}{$\begin{array}{l}\text { High } \\
\text { income } \\
\text { countries }\end{array}$} & \multirow{2}{*}{ Geographic region } \\
\hline & Lower & Upper & & \\
\hline $\begin{array}{l}\text { Somalia } \\
\text { Yemen } \\
\text { Syria }\end{array}$ & $\begin{array}{l}\text { Sudan } \\
\text { Morocco } \\
\text { Tunis } \\
\text { Djibouti } \\
\text { Palestine } \\
\text { Egypt } \\
\text { Mauritania }\end{array}$ & $\begin{array}{l}\text { Jordan } \\
\text { Algeria } \\
\text { Iraq } \\
\text { Iran } \\
\text { Turkey } \\
\text { Lebanon } \\
\text { Libya }\end{array}$ & $\begin{array}{l}\text { Arab } \\
\text { Emirates } \\
\text { Israel } \\
\text { Bahrain } \\
\text { Saudi } \\
\text { Arabia } \\
\text { Kuwait } \\
\text { Oman } \\
\text { Qatar }\end{array}$ & $\begin{array}{l}\text { The Middle East and } \\
\text { North Africa } \\
\text { (MENA) region }\end{array}$ \\
\hline
\end{tabular}

Table (D): Results of the normal pattern regression of Infrastructure needs

Method: Pooled OLS

White cross-section standard errors \& covariance (no d.f. correction)

\begin{tabular}{|c|c|c|c|c|c|}
\hline & $\begin{array}{l}\text { Transp } \\
\text { ort }\end{array}$ & $I C T$ & $\begin{array}{l}\text { Financ } \\
e\end{array}$ & Energy & Total \\
\hline $\begin{array}{l}\text { GDP } \\
\text { capita }\end{array}$ & $\begin{array}{l}1.0519 \\
{\left[\begin{array}{l}25.79 \\
* *\end{array}\right.}\end{array}$ & $\begin{array}{l}0.9459 \\
{\left[\begin{array}{l}15.02 \\
* *\end{array}\right.}\end{array}$ & $\begin{array}{l}0.4278 \\
{\left[\begin{array}{l}10.43]^{*} \\
* *\end{array}\right.}\end{array}$ & $\begin{array}{l}\mathbf{0 . 9 9 3 8} \\
{\left[\begin{array}{l}53.14 \\
* *\end{array}\right.}\end{array}$ & $\begin{array}{l}1.2172 \\
{\left[\begin{array}{l}17.81 \\
* *\end{array}\right.}\end{array}$ \\
\hline Area & $\begin{array}{l}-\mathbf{- 0 . 2 2 8 3} \\
{[-} \\
7.216] * \\
* *\end{array}$ & $\begin{array}{l}-\mathbf{- 0 . 2 3 4 9} \\
{[-} \\
10.86]^{*} \\
* *\end{array}$ & $\begin{array}{l}\mathbf{- 0 . 3 3 8 7} \\
{[-} \\
\mathbf{1 0 . 8 3}]^{*} \\
* *\end{array}$ & $\begin{array}{l}\mathbf{- 0 . 2 8 2 7} \\
{[-} \\
21.55]^{*} \\
* *\end{array}$ & $\begin{array}{l}\mathbf{- 0 . 4 0 5 9} \\
{[-} \\
12.55]^{*} \\
* *\end{array}$ \\
\hline
\end{tabular}




\begin{tabular}{|c|c|c|c|c|c|}
\hline Populatio & 1.2519 & 0.5269 & 0.1441 & 0.6118 & 0.9769 \\
\hline$n$ & [ & {[} & [ & [ & [ \\
\hline & $\underbrace{19.77]^{*}}_{* *}$ & $\underset{* *}{10.06}]^{*}$ & $\begin{array}{l}\text { 3.279]* } \\
* *\end{array}$ & $\begin{array}{l}\text { 20.63] } \\
* *\end{array}$ & $\begin{array}{l}\text { 16.06]* } \\
* *\end{array}$ \\
\hline
\end{tabular}

$\begin{array}{llllll}\text { Constant } & -27.136 & -13.907 & -1.9339 & -15.211 & -22.115\end{array}$

$[-\quad[-\quad[-\quad[-\quad[-$

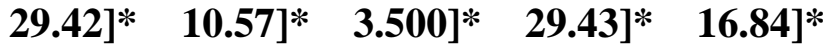

$* * \quad * * \quad * * \quad * * \quad * *$

\begin{tabular}{llllll}
\hline Observati & 225 & 345 & 236 & 289 & 146
\end{tabular}

ons

$\begin{array}{llllll}\text { Adjusted } & 0.589 & 0.587 & 0.339 & 0.743 & 0.691\end{array}$

$\mathbf{R}^{2}$

N.B.: ***,**** indicate significance at the level of $1 \%, 5 \%$ and $10 \%$ respectively. 
